\title{
Seasonal Pattern of Abundance of Aedes aegypti (Diptera: Culicidae) in Buenos Aires City, Argentina
}

\author{
Darío Vezzani ${ }^{+}$, Stella Maris Velázquez, Nicolás Schweigmann
}

\author{
Unidad de Ecología de Reservorios y Vectores de Parásitos, Departamento de Ecología, Genética y Evolución, Facultad de \\ Ciencias Exactas y Naturales, Universidad de Buenos Aires, Ciudad Universitaria, Pabellón II, $4^{\circ}$ piso, C1428EHA \\ Buenos Aires, Argentina
}

\begin{abstract}
In Buenos Aires, the most crowded city of Argentina, there is a potential risk of dengue virus transmission by the mosquito Aedes aegypti during late summer. The temporal patterns of oviposition activity and abundance of breeding sites of this vector were studied in two cemeteries of the city. Between September 1998 and August 1999, we examined 142 ovitraps weekly and a total of 18,010 water-filled containers. Both study areas showed remarkable differences in the percentages of positive ovitraps (19\% vs 8\%) and breeding sites (18\% vs 1\%), but similar temporal abundance patterns. The percentage of breeding sites was higher in summer and autumn than in spring and winter, and the percentage of positive ovitraps was higher in summer than in the other three seasons. Immatures were recorded from the first week of October to the second week of July, and oviposition activity from the third week of October until the end of April. In both cemeteries and with both methodologies the highest infestation levels were registered in March (ovitraps: $41.8 \%$ and 20.6\%, breeding sites: $39.2 \%$ and 3.4\%). These highest abundances took place after several months with mean temperatures above $20^{\circ} \mathrm{C}$ and accumulated rainfalls above $150 \mathrm{~mm}$. A sharp decline in oviposition activity was observed when monthly mean temperature decreased to $16.5^{\circ} \mathrm{C}$, and no eggs were found below $14.8^{\circ} \mathrm{C}$. Seasonal fluctuation of Ae. aegypti abundances in mid-latitudes like Buenos Aires would allow reduction of the egg mosquito population through the elimination of containers during the coldest months, which are free of adults.
\end{abstract}

Key words: Aedes aegypti - abundance pattern - ovitraps - breeding sites - Buenos Aires

Aedes aegypti (L.), the main dengue vector, was considered eradicated from Argentina in 1963 as a result of the Continental Campaign for vector elimination (Carcavallo \& Martínez 1968). Reinfestation was detected in 1986 (OPS 1990) and currently the geographic distribution of the mosquito is wider than before eradication (Curto et al. 2002). Recently, three important dengue outbreaks were reported from Northern Argentina in the provinces of Salta (1998), Misiones and Formosa (2000) (Boletín Epidemiológico Nacional 2001), involving 922 confirmed cases (Avilés et al. 2003). In Buenos Aires, there is a potential risk of dengue virus transmission during late summer (Carbajo et al. 2001), but no autochthonous cases of the disease have been detected until present. However, some clinical studies documented dengue infection in people arriving from border countries with epidemics (Seijo et al. 2000, 2001). The occasional presence of dengue virus in people, together with high infestation levels of the vector (Cardinal et al. 2000, Vezzani et al. 2001, Schweigmann et al. 2002), pose an actual risk of virus transmission in Buenos Aires, the most crowded urban center of Argentina.

Financial support: Conicet

${ }^{+}$Corresponding author. Fax: +54-11-4576-3384. E-mail: vzztato@fibertel.com.ar

Received 8 December 2003

Accepted 27 May 2004
In general, insects are exceedingly sensitive to temperature and rainfall regimens, and tropical and temperate species frequently show great variations in seasonal abundance (Samways 1995). Reproduction of Ae. aegypti populations from tropical and subtropical zones occurs all year round and their abundance can either be associated with rainfall regimens (Moore et al. 1978, Chadee 1991, 1992, Kalra et al. 1997, Micieli \& Campos 2003) or not (Sheppard et al. 1969, Barrera et al. 1997). In temperate regions, temperature fluctuations affect the mosquito populations and allow Ae. aegypti proliferation only between September and April in Buenos Aires (de Garín et al. 2000). Ae. aegypti populations are likely to remain as eggs through cold months (Domínguez et al. 2000, Schweigmann et al. 2002), and larvae might be occasionally found within small patches providing extraordinary favourable conditions (Kuruc et al. 2001).

Urban cemeteries frequently fulfil the requirements for the proliferation of container-inhabiting mosquitoes. In particular, cemeteries of Buenos Aires City showed levels of Ae. aegypti infestation similar to mean values observed in the rest of the city (Vezzani et al. 2001). Using cemeteries as a study model, the objective of this work was to determine the temporal patterns of oviposition activity and abundance of breeding sites of Ae. aegypti in Buenos Aires City.

\section{MATERIALSAND METHODS}

Study area - Buenos Aires City (343'ㅇ 58 29'W), Argentina, is located at a mean altitude of $25 \mathrm{~m}$ above sea level. It has a diameter of approximately $17 \mathrm{~km}$ and covers an area of about $200 \mathrm{~km}^{2}$. There are approximately three 
million people living in the city and nine million in surrounding urban areas. Climate is temperate-humid with marked seasonality. The annual mean precipitation is 1076 $\mathrm{mm}$ and mean temperature is $17.4^{\circ} \mathrm{C}$ (IGM 1998).

The study was conducted in cemeteries Británico (BR) and Chacarita $(\mathrm{CH})$, which are adjacent and located near the geographic center of the city. These cemeteries were selected based on their contrasting environmental features and Ae. aegypti container indexes (percentage of water-holding containers infested with larvae or pupae, PAHO 1994). BR is a private cemetery with high vegetation cover $(82 \%)$ and high container index (25\%). On the other hand, $\mathrm{CH}$, which is administered by municipal authorities, has medium vegetation cover $(26 \%)$ and low container index (1.3\%) (Vezzani et al. 2001).

Methodology - Temporal variations of Ae. aegypti abundance were evaluated by two techniques: (a) monitoring of breeding sites, and (b) monitoring of oviposition activity.

The monitoring of breeding sites (a) consisted of weekly inspections of randomly selected containers (any receptacle capable of containing water), which could not be re-sampled within a one-month period to avoid pseudoreplications. The water in each container was filtered with a fine mesh strainer. All preimaginal stages collected were fixed in $70 \%$ ethanol, examined with stereoscopic microscope at 50X, and identified according to the key for Argentine mosquitoes (Darsie 1985). Third and fourth instars and pupae were counted. The frequency of occurrence of other mosquito species was not assessed.

In $\mathrm{CH}$, containers were examined weekly (median = 766 , quartile $1=688$, quartile $3=807$ ) from the beginning of November 1998 until the end of May 1999. In BR, containers were examined weekly $($ median $=299$, quartile $1=$ 272 , quartile $3=333$ ) from the beginning of October 1998 to the end of August 1999.

Oviposition was monitored (b) weekly using conventional black glass jar ovitraps (Service 1976) that were homogeneously distributed in both study areas. Each ovitrap, with a capacity of $330 \mathrm{ml}$, contained $100 \mathrm{ml}$ of water and a $3 \times 10 \mathrm{~cm}$ hardboard paddle resting against the upper rim. Each paddle was replaced seven days after exposure. Eggs of Ae. aegypti were examined under stereoscopic microscope (50X), identified according to descriptions by Estrada-Franco and Craig (1995), and counted.

In $\mathrm{CH}, 131$ ovitraps (1.8 ovitraps/ha) were inspected weekly from the beginning of September 1998 until the end of April 1999. In BR, 11 ovitraps (2.2 ovitraps/ha) were examined weekly from the beginning of November 1998 to the end of August 1999.

Data analysis - The percentage of Ae. aegypti breeding sites was defined as the percentage of water-holding containers infested with at least one larva or pupa. Percentages of Ae. aegypti breeding sites and percentages of positive ovitraps (with eggs) were compared between cemeteries with the $\mathrm{z}$ test for two independent proportions (Fleiss 1981). Such comparison was undertaken using mean values obtained during the period when both cemeteries were simultaneously studied (breeding sites: November 98-May 99; ovitraps: November 98-April 99).
Additionally, separate $\mathrm{z}$ tests were performed for each month in which data exist for both BR and $\mathrm{CH}$.

The productivity of immatures per breeding site (median number of third and fourth instar and pupae) and the productivity of eggs per ovitrap (median number of eggs per ovitrap) were compared between cemeteries using the Mann-Whitney test (Siegel \& Castellan 1995).

Seasonality was studied in each cemetery by comparing the infestation levels among the four seasons with a $\chi^{2}$ test for multiple proportions (Fleiss 1981). Then, new tests for multiple proportions were performed using Tukey procedure, which permits the comparison of each value with every other value (Zar 1999). A descriptive analysis of the fluctuations in Ae. aegypti abundance was made using weekly and monthly values of breeding sites and oviposition activity, and monthly values of median number of immatures and median number of eggs.

Finally, we evaluated the association of mosquito abundance with monthly precipitation and temperature, which were calculated from daily data provided by the National Meteorology Service.

\section{RESULTS}

A total of 1069 breeding sites of Ae. aegypti were found among the 18,010 water-filled containers examined. The percentage of breeding sites in BR $(18.36 \%)$ was significantly higher $(\mathrm{z}=39.23, \mathrm{p}<0.001)$ than that in $\mathrm{CH}(0.98 \%)$. This difference of infestation between cemeteries was significant $(\mathrm{p}<0.001)$ during all months studied.

The difference in the percentage of positive ovitraps between areas was also significant $(\mathrm{z}=6.07, \mathrm{p}<0.001)$, with higher values in BR (19.6\%) than in $\mathrm{CH}(8.5 \%)$. Monthly comparison of oviposition activity between cemeteries showed significant differences in December $(\mathrm{p}<$ $0.001)$, January $(\mathrm{p}<0.001)$ and March $(\mathrm{p}<0.01)$.

Despite the significant differences in infestation of breeding sites and positive ovitraps between areas, productivity of eggs per positive ovitrap did not show a significant difference between cemeteries $(U=7,603, p=0.45$; BR: median $=7.5$, quartile $1=3$, quartile $3=12 ; \mathrm{CH}$ : median $=8$, quartile $1=3$, quartile $3=19$ ). Immature productivity per breeding site showed a difference only marginally significative between areas $(\mathrm{U}=35,687, \mathrm{p}=0.053$; $\mathrm{BR}$ : median $=5$, quartile $1=2$, quartile $3=12 ; \mathrm{CH}$ : median $=3.5$, quartile $1=2$, quartile $3=11.3$ ).

In regard to seasonality (Table), the percentage of breeding sites showed significant differences among seasons, both in BR $\left(\chi^{2}{ }_{3}=726.04, \mathrm{p}<0.001\right)$ and in $\mathrm{CH}$ $\left(\chi_{(2)}^{2}=30.66, p<0.001\right)$; in both cemeteries, the percentages of breeding sites did not differ between summer and autumn ( $p>0.05)$ and were significantly higher than those in spring and winter $(\mathrm{p}<0.001)$. Likewise, the percentage of positive ovitraps showed significant differences among seasons (BR: $\chi^{2}{ }_{(3)}=56.34, \mathrm{p}<0.001 ; \mathrm{CH}: \chi_{(3)}^{2}=335, \mathrm{p}<$ 0.001 ); in both cemeteries, the values obtained in summer were significantly higher than those in the other seasons $(\mathrm{p}<0.001)$.

The presence of immature stages of Ae. aegypti was recorded from the first week of October to the second week of July (Fig. 1a, b). Values increased gradually until March and decreased steadily between April and July. 
Maximum infestation of breeding sites was reached in March for both cemeteries (BR: 39.2\%, CH: 3.4\%). The dynamics of immature productivity per breeding site (both cemeteries together) (Fig. 2a) and the percentage of breeding sites were similar. The maximum monthly median number of immatures was 7 (quartile $1=3$, quartile $3=14.7$ ) in March, and the maximum absolute value recorded in a breeding site was 114 immatures during the last week of March.

Oviposition activity was recorded from the third week of October until the end of April (Fig. 3a, b); a considerably shorter period than that in which breeding sites were found. However, oviposition in $\mathrm{CH}$ was detected during November and December, but no larvae were found. The percentage of positive ovitraps increased gradually until March and showed a sharp decrease in April. The highest oviposition activity was registered in March for both cemeteries (BR: $41.8 \%, \mathrm{CH}: 20.6 \%$ ). The monthly productivity of eggs per ovitrap (Fig. 2b) showed a similar trend to the monthly percentage of positive ovitraps. The maximum monthly median of eggs was 10.5 (quartile $1=5$, quartile 3 $=19.2$ ) in March, and the maximum absolute value registered in one ovitrap was 183 eggs during the third week of March.

In general terms, the highest proliferation of mosquitoes occurred during months with highest temperature and precipitation. Meteorological conditions, with mean temperatures above $20^{\circ} \mathrm{C}$ and accumulated rainfalls above $150 \mathrm{~mm}$, were similar in Buenos Aires City during December, January, February, and March (Fig. 4). However, infestation levels among these months differed significantly in both cemeteries and with both methodologies (monitoring of breeding sites and monitoring of oviposition activity). Highest abundances were recorded in March, after several months with favourable conditions for vector development. A sharp decline in oviposition activity

TABLE

Seasonal percentages of Aedes aegypti breeding sites and positive ovitraps in cemeteries Británico and Chacarita

\begin{tabular}{lccccc}
\hline & \multicolumn{2}{c}{$\begin{array}{c}\text { Percentage of breeding sites } \\
\text { (number of positive containers/ } \\
\text { number of water-holding containers) }\end{array}$} & & \multicolumn{2}{c}{$\begin{array}{c}\text { Percentage of positive ovitraps } \\
\text { (number of positive ovitraps/ } \\
\text { number of total ovitraps) }\end{array}$} \\
\cline { 2 - 3 } Seasons & Británico & Chacarita & & Británico & Chacarita \\
\hline Spring & $2.68(56 / 2088)$ & $0.00(0 / 2157)$ & & $7.79(6 / 77)$ & $0.57(9 / 1572)$ \\
Summer & $22.65(494 / 2181)$ & $1.08(48 / 4456)$ & & $28.67(41 / 143)$ & $14.74(251 / 1703)$ \\
Autumn & $19.51(415 / 2127)$ & $1.49(50 / 3358)$ & & $6.29(9 / 143)$ & $3.82(30 / 786)$ \\
Winter & $0.37(6 / 1643)$ & nd & & $0.00(0 / 99)$ & $0.00(0 / 524)$ \\
\hline
\end{tabular}

nd: no data
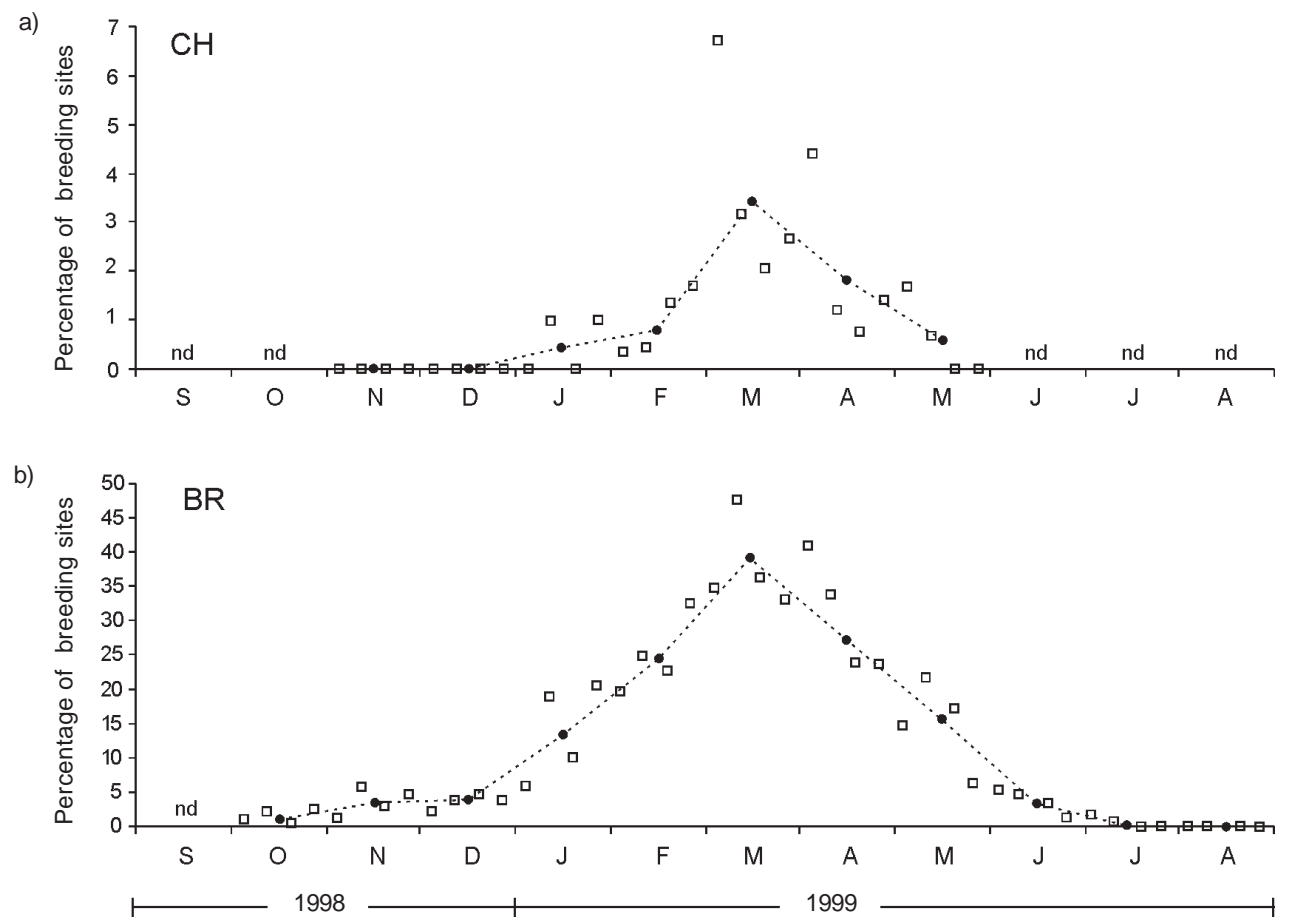

Fig. 1: weekly ( $\square$ ) and monthly (......) percentages of Aedes aegypti breeding sites in cemeteries Chacarita (a) and Británico (b); nd: no data; period September 1998-August 1999 

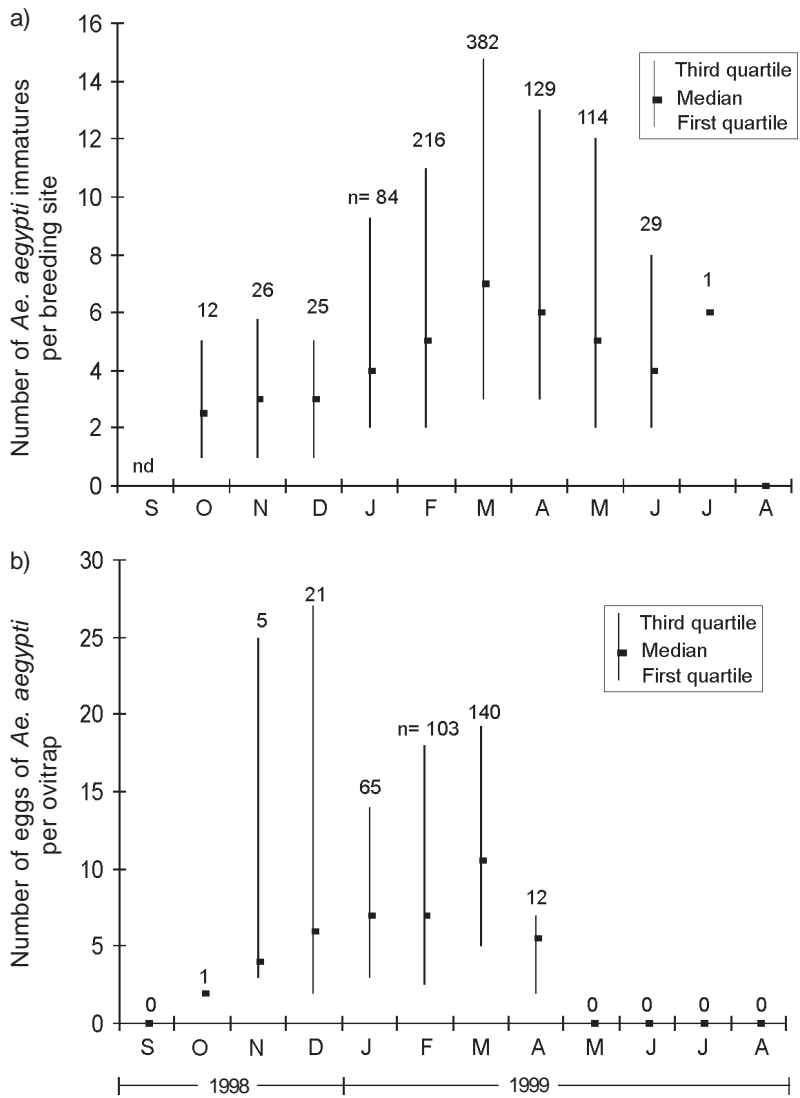

Fig. 2: monthly productivity of immatures per breeding site (a) and monthly productivity of eggs per ovitrap (b), considering both cemeteries together; nd: no data; period September 1998-August 1999

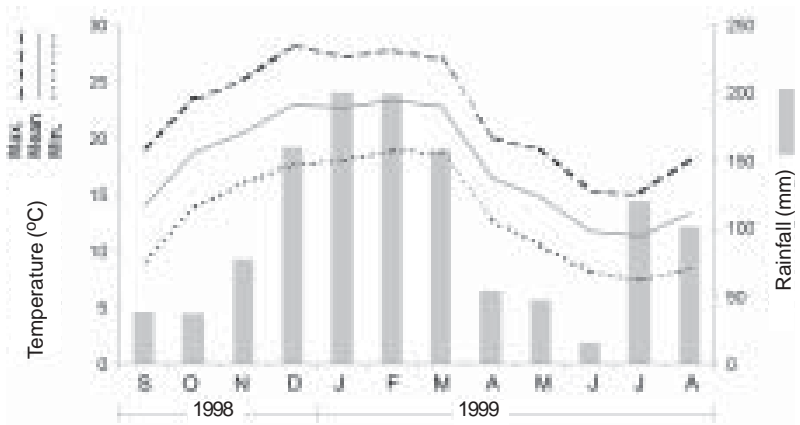

Fig. 4: meteorological conditions (temperature and precipitation) in Buenos Aires City during the period September 1998-August 1999 (National Meteorology Service)

was observed when monthly mean temperature decreased to $16.5^{\circ} \mathrm{C}$ (April), and no eggs were found below $14.8^{\circ} \mathrm{C}$ (May).

\section{DISCUSSION}

The significant differences in the percentages of breeding site infestation and positive ovitraps between both studied areas, were probably due to different habitat quality, as we concluded in a previous study (Vezzani et al. 2001). Despite these contrasting results, both areas showed similar patterns of variation in Ae. aegypti population growth.

The mosquito population dynamics showed similar seasonal pattern using both positive ovitraps and breeding containers. The main differences observed between methods were that the beginning of reproductive activity was more effectively detected with ovitraps than the in-

a)

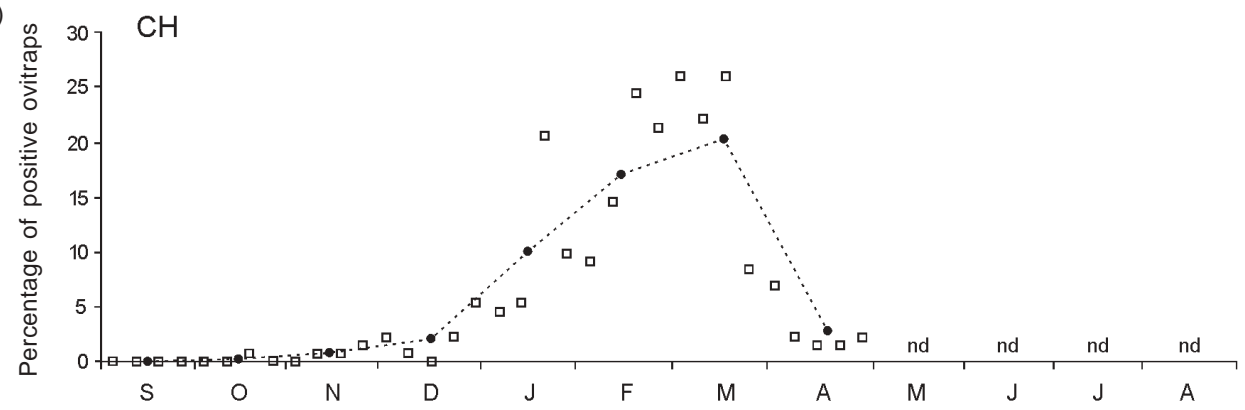

b)

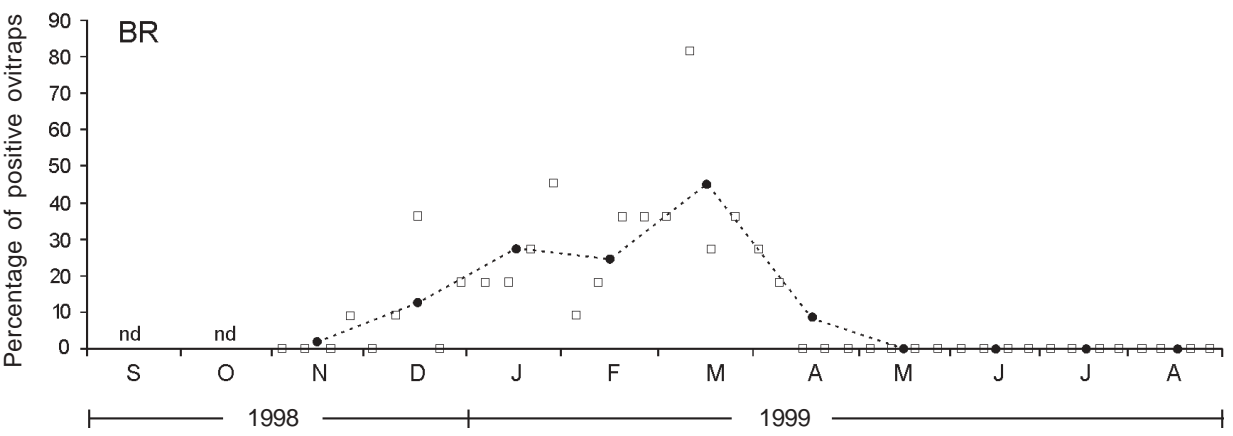

Fig. 3: weekly ( $\square$ ) and monthly (......) percentages of positive ovitraps in cemeteries Chacarita (a) and Británico (b); nd: no data; period September 1998-August 1999 
spection of breeding sites, and that higher infestation variations was seen with the inspection of breeding sites than ovitraps. In a comprehensive review of the methods used to study Ae. aegypti, Focks (2003) concluded that the ovitrap is an excellent tool to detect the presence of the vector and to compare infestations among different periods of the year, but it does not seem to be appropriate for comparisons of vector abundance between areas during the same period of the year.

In regard to population dynamics, larvae found at the beginning of October probably hatched from eggs laid in the previous reproductive season, since mean temperatures above $17^{\circ} \mathrm{C}$ that are required for successful hatching (Christophers 1960) are registered from October onward, and consequently reproductive season (defined by ovipositioning) would begin at the end of October. Although optimum temperatures for vector proliferation are registered from December onward (Christophers 1960), maximum abundances of immatures and eggs were observed in March. This delay in the numerical increase experienced from November onward may indicate that the population was recovering from low winter abundances. During March, highest infestation levels have also been observed in other areas of the country, such as Quilmes City (Campos \& Maciá 1996), La Plata City (García et al. 2002), Chaco Province (Stein \& Oria 2002), and Salta Province (Micieli \& Campos 2003).

The decline in oviposition activity, reflecting the end of the reproductive season, was closely associated with decrease in temperature. Campos and Maciá (1996) for Buenos Aires Province, and Domínguez et al. (2000) for Córdoba City, pointed out that the thermal threshold for oviposition is $17^{\circ} \mathrm{C}$. In the locality of Quilmes, next to Buenos Aires City, Campos and Maciá (1996) found larvae until June whereas in the present study a few larvae were found in July; in both cases, pupae were not observed at these dates. These findings could partially explain winter mortality, since hatch and immature growth without adult emergence can occur at low temperatures (Christophers 1960, Clements 1992). At mid-latitudes like Buenos Aires, reproduction of mosquito populations is discontinued as a result of low winter temperatures; abundances would be regulated mainly by temperature rather than precipitation (Campos \& Maciá 1996, Schweigmann et al. 2002). In Northern Argentina, reproduction of $A e$. aegypti populations probably occurs all year round due to high temperatures, as for example in Corrientes City (Borda et al. 1999) and Salta Province (Micieli \& Campos 2003).

The number of eggs per ovitrap within cemeteries was remarkably lower than that observed in the rest of the city (cemeteries: median $=8$, mean $=14$; city: median $=15$, mean $=25$, unpublished observations). Females of $A e$. aegypti lay a few eggs in several containers, a behaviour described as skip oviposition (Chadee 1992, Corbet \& Chadee 1993, Reiter et al. 1995, Colton et al. 2003). Within cemeteries, this oviposition behaviour would be favoured by the free access to numerous sites suitable for oviposition, which are placed at short distances apart from each other. Therefore, the lower values recorded in cemeteries when compared to other places, suggest that females dis- tribute a smaller number of eggs in more containers. In Buenos Aires, mean numbers of eggs per ovitrap are within the range of mean values mentioned for other American countries (between 11 and 32 eggs) (Chadee 1992, 1993, Reiter et al. 1995, Yan et al. 1999, Colton et al. 2003).

The seasonal fluctuation of abundances described in this study may allow to determine the most appropriate periods for the implementation of control measures. During the approximately five months, that are free of adults (the cold season), elimination of containers would help to reduce vector population efficiently (mainly eggs) with no risk of enhancement of adult dispersal (Reiter et al. 1995, Edman et al. 1998). This would save time and money. However, according to Scott et al. (2000), the components of Ae. aegypti biology can vary among and within communities as well as among years at the same location, and care should be taken when extrapolating results from one site to another and from one year to the next. Consequently, a longitudinal study covering several consecutive years in different areas of Buenos Aires City is needed to confirm our results.

\section{ACKNOWLEDGEMENTS}

To the authorities of the cemeteries and to the technical assistants of the Government of Buenos Aires City for their help in the field work. To Silvia Pietrokovsky for her critical review of the manuscript.

\section{REFERENCES}

Avilés G, Paz MV, Rangeon G, Ranaivoarisoa MY, Verzeri N, Roginski S, Baroni P, Enria D 2003. Laboratory surveillance of dengue in Argentina, 1995-2001. Emerg Infect Dis 9: 738-742.

Barrera R, Avila J, Navarro J 1997. Dinámica poblacional de Aedes aegypti (L.) en centros urbanos con deficiencia en el suministro de agua. Acta Biol Venez 17: 23-35.

Boletín Epidemiológico Nacional 2001. Boletin Epidemiológico Nacional 2000-2001, Ministerio de Salud, Secretaría de Atención Sanitaria, Subsecretaría de Programa de Promoción y Prevención, Dirección de Programas Sanitarios, Dirección de Epidemiología, República Argentina, 45 pp.

Borda CE, Rea MFJ, Rosa JR, Mosqueda LA, Sario H 1999. Vector de la fiebre amarilla urbana y el dengue en la ciudad de Corrientes, Argentina. Comunicaciones Científicas y Tecnológicas de la Universidad Nacional del Nordeste, Argentina, http://www.unne.edu.ar/cyt/cyt2000.htm

Campos RE, Maciá A 1996. Observaciones biológicas de una población natural de Aedes aegypti (Diptera: Culicidae) en la provincia de Buenos Aires, Argentina. Rev Soc Entomol Argent 55: 67-72.

Carbajo AE, Schweigmann N, Curto SI, de Garin A, Bejarán R 2001. Dengue transmission risk maps of Argentina. Trop Med Int Health 6: 170-183.

Carcavallo RU, Martínez A 1968. Fiebre amarilla, vectores y cadena epidemiológica. In RU Carcavallo, A Martinez (eds), Entomoepidemiología de la República Argentina, XXIII Comunicaciones Científicas de las Fuerzas Armadas, Buenos Aires, p. 105-144.

Cardinal MV, Lanati LA, Rubio A, Kuruc JA, Hernández Penna S, Mazzone G, Albioni GE, Gutiérrez ML, Reichmann L, Iturriaga M, Dure Ruiz NM, Pirk GI, Schweigmann N 2000. Infestación domiciliaria por formas inmaduras de Aedes aegypti (Diptera: Culicidae) en la Capital Federal. Jornada Regional Sobre Mosquitos, Buenos Aires, Argentina, p. 6667. 
Chadee DD 1991. Seasonal incidence and vertical distribution patterns of oviposition by Aedes aegypti in an urban environment in Trinidad, W. I. J Am Mosq Control Assoc 7: 383-386.

Chadee DD 1992. Seasonal incidence and horizontal distribution patterns of oviposition by Aedes aegypti in an urban environment in Trinidad, West Indies. J Am Mosq Control Assoc 8: 281-284.

Chadee DD 1993. Oviposition response of Aedes aegypti (L.) to the presence of conspecific eggs in the field in Trinidad, W.I. J Florida Mosq Control Assoc 64: 63-66.

Christophers R 1960. Aedes aegypti (L.), the Yellow Fever Mosquito, Cambridge Univ Press, Cambridge, 739 pp.

Clements AN 1992. The Biology of Mosquitoes, Chapman \& Hall, London, 509 pp.

Colton YM, Chadee DD, Severson DW 2003. Natural skip oviposition of the mosquito Aedes aegypti indicated by codominant genetic markers. Med Vet Entomol 17: 195-204.

Corbet PS, Chadee DD 1993. An improved method for detecting substrate preferences shown by mosquitoes that exhibit 'skip oviposition'. Physiol Entomol 18: 114-118.

Curto SI, Boffi R, Carbajo AE, Plastina R, Schweigmann N 2002. Reinfestación del territorio argentino por Aedes aegypti. Distribución geográfica (1994-1999). In OD Salomón, Actualizaciones en Artropodología Sanitaria Argentina, Publicación Monográfica 2, Buenos Aires, p. 127137.

Darsie Jr RF 1985. Mosquitoes of Argentina. Part I. Keys for identification of adult females and fourth stage larvae in English and Spanish (Diptera, Culicidae). Mosq Syst 17: 153-253.

de Garín A, Bejarán RA, Carbajo AE, C de Casas S, Schweigmann N 2000. Atmospheric control of Aedes aegypti populations in Buenos Aires (Argentina) and its variability. Int $J$ Biometeorol 44: 148-156.

Domínguez C, Ludueña Almeida FF, Almirón W 2000. Dinámica poblacional de Aedes aegypti (Diptera: Culicidae) en Córdoba Capital. Rev Soc Entomol Argent 59: 41-50.

Edman J, Scott T, Costero A, Morrison AC, Harrington LC, Clark GG 1998. Aedes aegypti (Diptera: Culicidae) movement influenced by availability of oviposition sites. J Med Entomol 35: 578-583.

Estrada-Franco JG, Craig Jr GB 1995. Biology, Disease Relationships, and Control of Aedes albopictus, Pan American Health Organization, Technical Paper 42, 51 pp.

Fleiss JL 1981. Statistical Methods for Rates and Proportions, John Wiley \& Sons, US, 255 pp.

Focks DA 2003. A Review of Entomological Sampling Methods and Indicators for Dengue Vectors, World Health Organization, Tropical Disease Research, 35 pp.

García JJ, Micieli MV, Achinelly MF, Marti GA 2002. Establecimiento de una población de Aedes aegypti L. en La Plata, Argentina. In OD Salomón, Actualizaciones en Artropodología Sanitaria Argentina, Publicación Monográfica 2, Buenos Aires, p. 149-153.

IGM 1998. Atlas Geográfico de la República Argentina, Instituto Geográfico Militar, Buenos Aires, Argentina.

Kalra NL, Kaul SM, Rastogi RM 1997. Prevalence of Aedes aegypti and Aedes albopictus - Vectors of Dengue and Dengue haemorrhagic fever in North, North-East and Central India. Dengue Bull 21: 84-92.

Kuruc J, Cardinal M, Rubio A, Albioni G, Lanati L, Mazzone L, Hernández Penna S, Ferreyra S, Pirk G, Gutierrez M, Orellano P, Vezzani D 2001. Aedes aegypti (L.) durante los meses de baja temperatura en la ciudad de Buenos Aires: Sitios prioritarios para su control. II Congreso Lati- noamericano de Zoonosis, Buenos Aires, Argentina.

Micieli MV, Campos RE 2003. Oviposition activity and seasonal pattern of a population of Aedes (Stegomyia) aegypti (L.) (Diptera: Culicidae) in Subtropical Argentina. Mem Inst Oswaldo Cruz 98: 659-663.

Moore CG, Cline BL, Ruiz-Tibén E, Lee D, Romney-Joseph H, Rivera-Correa E 1978. Aedes aegypti in Puerto Rico: environmental determinants of larval abundance and relation to dengue virus transmission. Am J Trop Med Hyg 27: $1225-1231$.

OPS 1990. Las Condiciones de la Salud en las Américas, Organización Panamericana de la Salud, Publicación Científica 524, Vol. 1, 503 pp.

PAHO 1994. Dengue and Dengue Hemorrhagic Fever in the Americas: Guidelines for Prevention and Control, Pan American Health Organization, Scientific Publication 548, 98 pp.

Reiter P, Amador MA, Anderson RA, Clark GG 1995. Dispersal of Aedes aegypti in an urban area after blood feeding as demonstrated by rubidium-marked eggs. Am J Trop Med Hyg 52: 177-179.

Samways MJ 1995. Insect Conservation Biology, Chapman \& Hall, London, 358 pp.

Schweigmann N, Orellano P, Kuruc J, Vera MT, Vezzani D, Méndez A 2002. Distribución y abundancia de Aedes aegypti (Diptera: Culicidae) en la ciudad de Buenos Aires. In OD Salomón, Actualizaciones en Artropodología Sanitaria Argentina, Publicación Monográfica 2, Buenos Aires, p. 155160.

Scott TW, Morrison AC, Lorenz LH, Clark GG, Strickman D, Kittayapong P, Zhou H, Edman JD 2000. Longitudinal studies of Aedes aegypti (Diptera: Culicidae) in Thailand and Puerto Rico: population dynamics. J Med Entomol 37: 7788.

Seijo A, Cernigoi B, Deodato B 2001. Dengue importado del Paraguay a Buenos Aires. Estudio clínico y epidemiológico de 38 casos. Medicina (Bs As) 61: 137-141.

Seijo A, Curcio D, Avilés G, Cernigoi B, Deodato B, Lloveras S 2000. Imported Dengue in Buenos Aires, Argentina. Emerg Infect Dis 6: 655-656.

Service MW 1976. Mosquito Ecology. Field Sampling Methods, Applied Science Publishers Ltd, London, 583 pp.

Sheppard PM, MacDonald WW, Tonn RJ, Grabs B 1969. The dynamics of an adult population of Aedes aegypti in relation to dengue haemorrhagic fever in Bangkok. J Anim Ecol 38: 661-702.

Siegel S, Castellan NJ 1995. Estadística no Paramétrica: Aplicada a las Ciencias de la Conducta, Editorial Trillas, México, 437 pp.

Stein M, Oria GI 2002. Identificacion de criaderos de Aedes aegypti (Diptera: Culicidae) y cálculo de índices de infestación en la provincia del Chaco. In OD Salomón, Actualizaciones en Artropodología Sanitaria Argentina, Publicación Monográfica 2, Buenos Aires, p. 161-166.

Vezzani D, Velázquez SM, Soto S, Schweigmann N 2001. Environmental characteristics of the cementeries of Buenos Aires City (Argentina) and infestation levels of Aedes aegypti (Diptera: Culicidae). Mem Inst Oswaldo Cruz 96: 467-471.

Yan G, Romero-Severson J, Walton M, Chadee DD, Severson DW 1999. Population genetics of the yellow fever mosquito in Trinidad: comparisons of amplified fragment length polymorphism (AFLP) and restriction fragment length polymorphism (RFLP) markers. Mol Ecol 8: 951-963.

Zar JH 1999. Biostatistical Analysis, Prentice Hall, New Jersey, $663 \mathrm{pp}$. 